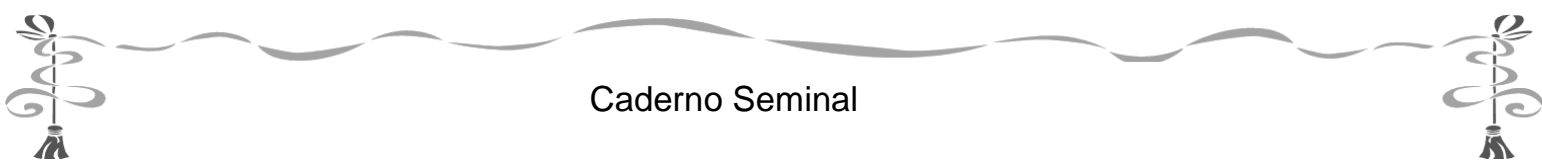

\title{
A PALAVRA E O RISO NAS CRÔNICAS DE JOÃO UBALDO RIBEIRO
}

\author{
THE WORD AND LAUGHING IN JOÃO UBALDO RIBEIRO'S CHRONICLES
}

Denise Salim Santos ${ }^{87}$

\section{Resumo}

Este artigo apresenta um estudo estilístico-discursivo, a partir dos processos de formação de palavras recorrentes na crônica jornalística de João Ubaldo Ribeiro que são relevantes na construção do humor presente nos textos analisados. Destaca o papel da composição e da derivação como desencadeadores do riso, através do enriquecimento semântico que trazem às crônicas, a partir da manipulação dos elementos morfológicos existentes no sistema da Língua Portuguesa.

Palavras-chave: Humor; Processos de Formação de Palavras; Estilística; Discurso

\section{Abstract}

This article presents a study of style-discursive, from the processes of word formation in chronic recurrent journalistic João Ubaldo Ribeiro which are relevant in the construction of the humor in the texts analyzed. Highlights the role of composition and derivation as triggers of laughter through semantic enrichment they bring to chronic, from the manipulation of morphological elements in the system of the Portuguese language.

Keywords: Humour; Processes oh word formation; Estilistic; Discourse.

\section{Preliminares}

Desde os primeiros pensamentos filosóficos, o riso vem atrelado à ideia de prazer. Ao rir, relaxamos dos fardos pesados que a vida nos impõe. Descansamos. Através do riso podemos enxergar a realidade de outra maneira e chegar à verdade do mundo pelo caminho autorizado do não sério. O riso também pode ser crítico, punitivo, instrumento de humilhação, controlador dos excessos sociais. Por isso, segundo Versiani (1974, p. 23) o homem teme ser ridículo: o riso é como a espuma das ondas do mar; parte superficial do entrechoque das ondas, ela ferve, chia - é a alegria. Mas ela é feita à base de sal; quando o filósofo vai prová-la, sentirá, para uma pequena quantidade de matéria, uma boa dose de amargor.

Rir faz a diferença entre os homens e seus inferiores - os animais e os seres inanimados. Só o homem tem a capacidade de rir. No entanto, o riso é instrumento de discriminação entre o Criador e a criatura. Deus não ri, segundo os cânones da Igreja. O sentimento de superioridade em relação àqueles, os animais, se esvai diante da inferioridade em relação ao Ser Absoluto, gerando a ambiguidade própria à condição humana de que o riso é prova por excelência.

Centrado inicialmente no objeto do riso, hoje não se concebe mais o riso sem levarse em conta a percepção do que ele significa, emprestada pelo sujeito que ri. O riso

${ }^{87}$ Professora de Língua Portuguesa - UERJ /FACHA. d.salim@globo.com

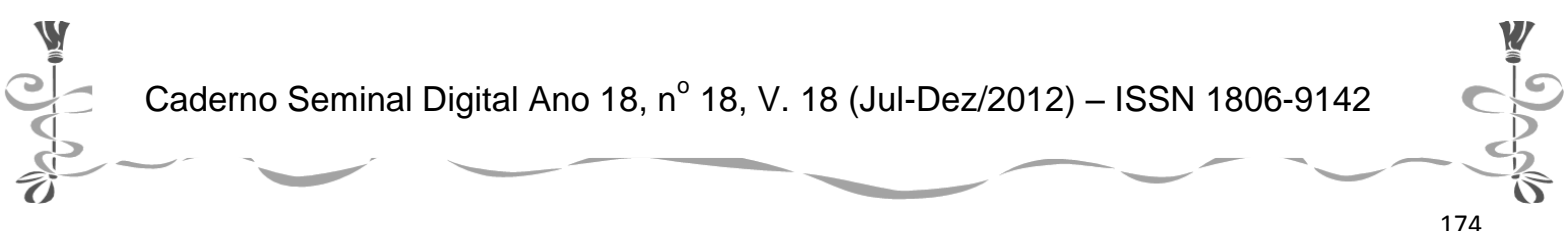




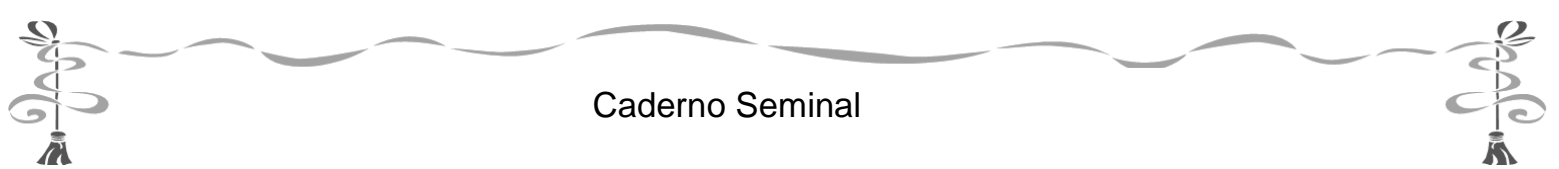

não é mais incompatível com a atividade humana. Já é viável colocar-se o "boné do bufão" para se ter uma nova visão do universo, para ir-se além do possível e atingir o impossível através do não sério. Por isso, talvez, nos dias de hoje se dê tanta importância àqueles que fazem do humor sua ferramenta de trabalho no combate às injustiças sociais, ao cerceamento das liberdades e na denúncia do que não está correto. O riso é uma terapêutica social. Por esse ou aquele viés, os teóricos acabam quase sempre por concordar com a ideia de que o riso faz bem à saúde mental, física e social.

As brevíssimas anotações feitas até aqui contextualizam o cômico, o riso e de seu objeto neste estudo. Em algumas passagens constatamos variações dos tipos de produção cômica. Uma delas é o humor, citado como uma especialização do cômico. Segundo Cabral e Nick (1974, p. 174) humor é a expressão verbal ou outra que retrata uma situaşão com misto de simpatia e divertimento on uma tendência para reagir favoravelmente (bom humor) ou desfavoravelmente (mau bumor) a outras pessoas.

Sigmund Freud enriquece a teorização sobre os estudos do humor, acrescentando que este tipo de cômico é um meio de se obter prazer apesar dos afetos (sentimentos) dolorosos que nele interferem. Situa-se neste ponto a primeira distinção entre o cômico e o humor: aquele não consegue existir em presença da dor, do sofrimento; ao passo que o humor atua exatamente como um substituto da geração de um sofrimento, ou seja, dando pouca importância a seus infortúnios, o indivíduo está apto a ver o lado "engraçado" da situação .

Segundo o psicanalista, o humor tem como fonte a economia de sentimento (compaixão). Aliás, todo processo de geração do riso é fundado no princípio da economia: o cômico, a partir da economia do pensamento e da representação; o chiste, a partir da economia da inibição.

Outra característica importante da situação humorística é que se satisfaz rapidamente, porque completa seu circuito dentro do próprio produtor do humor. A divulgação da satisfação que o humor produz no indivíduo não carece necessariamente da participação do outro para se completar ${ }^{88}$.

Quanto à funcionalidade, à semelhança do cômico, uma das mais evidentes está em seu papel de controlador social crítico. Como técnica de controle, é usado para as mais diversas manifestações de aprovação, desaprovação, hostilidade ou rejeição etc. Não é, no entanto, um recurso unilateral; é usado tanto pelos representantes do poder e da autoridade, quanto pelos demais grupos sociais, o que é bem mais frequente, uma vez que o humor pode se tornar instrumento de luta, de oposição.

${ }^{88}$ Sugerimos a leitura de Os chistes e sua relação com o inconsciente, de Sigmund Freud (Rio de Janeiro: Imago, 1977) para maior aprofundamento da perspectiva psicanalítica sobre a questão do cômico e do humor.

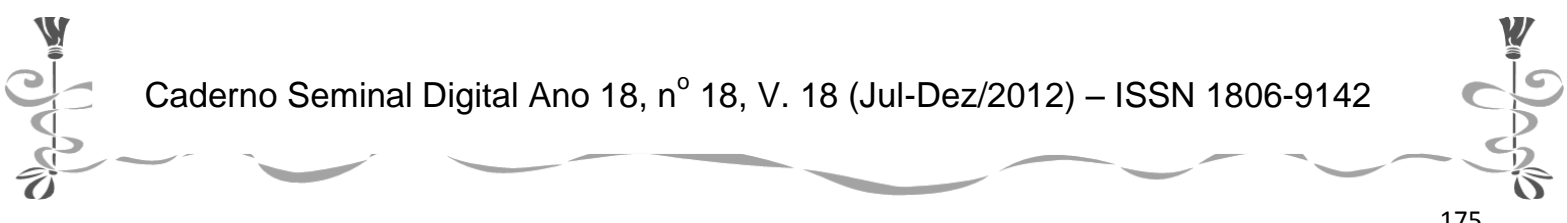




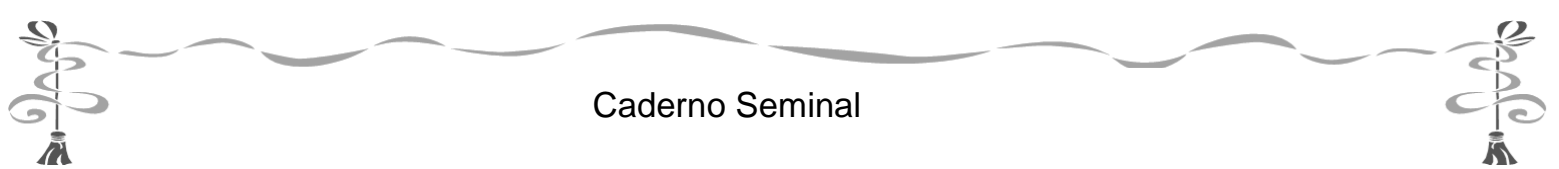

Sírio Possenti (1998: 49) concorda com a ideia, mas de forma parcial, denunciando a existência de um humor reacionário, nada progressista:

A afirmação segundo a qual o humor critica é muito parcial. O humor nem sempre é progressista. O que caracteriza o humor é muito provavelmente o fato de que ele permite dizer alguma coisa mais ou menos proibida, mas não necessariamente crítica, no sentido corrente, isto é, revolucionária, contrária a costumes arraigados e prejudiciais. $\mathrm{O}$ humor pode ser extremamente reacionário, quando é uma forma de manifestação do discurso veiculador de preconceitos, caso em que acaba sendo contrário a costumes que são de alguma forma bons, ou, pelo menos razoáveis, civilizados como os tendentes ao igualitarismo, sem dúvida melhores que os seus contrários. Como dizer que o humor é crítico nesses casos?

Os textos impregnados de humor vêm forjados por situações ambíguas. Embora suscitem hilaridade, normalmente são motivados por alguma situação que irrita, inquieta a opinião pública; o que nos leva a crer que, através do humor, tenta-se destruir a realidade que não agrada. Esses textos têm de ser construídos segundo técnicas eficientes, uma vez que o discurso humorístico não tem compromisso com manter relações de significação num mesmo sistema de referência. A justaposição de planos é fonte frequente desse tipo de efeito de sentido. Até porque as palavras não têm efeito exclusivo de produzir sentidos. Elas são manipuladas para chegar ao objetivo humorístico.

A temática explorada não foge à função social que o humor exerce. Dela fazem parte os assuntos controversos socialmente, na maior parte das vezes - sexo, política, racismo, instituições em geral, maternidade, a própria língua, loucura, defeitos físicos. Do discurso humorístico também são alvos fáceis a velhice, a calvície, a obesidade, o tamanho dos órgãos sexuais. De alguma forma o humorista descobrirá um artifício de veicular o subterrâneo, o não oficial em seu discurso.

Outro aspecto pertinente ao cômico, e que se mantém no humor, é o caráter lúdico. Eduardo Diatay Menezes (1974, p. 11-13) afirma que o cômico constitui uma categoria especial das atividades lúdicas, porquanto só sob o ponto de vista do jogo é que se pode perceber o objeto do riso. Segundo o autor, assim como o jogo, o cômico confronta-se com os fatos em favor da fantasia; é a negação do real através da ficção; é um meio de livrar-se de suas pressões e constrangimentos:

O jogo, como o cômico, está associado à alegria, ao prazer, à surpresa, ao arrebatamento, farsa, divertimento, realidade (...). À tendência a esquecer ou desconhecer os dados da vida real, ao desprezo pelo bom-senso, à concentração nos sonhos de glória e nos empreendimentos heroicos que compõem o cômico, correspondem o espírito de luta e aventura, conquista e superação que acompanham o jogo. Por outro lado a repetição é comum aos dois tipos de fenômenos.

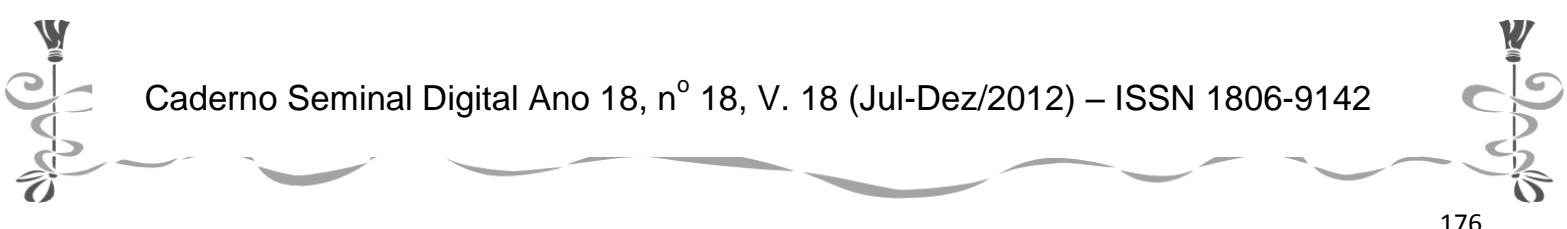




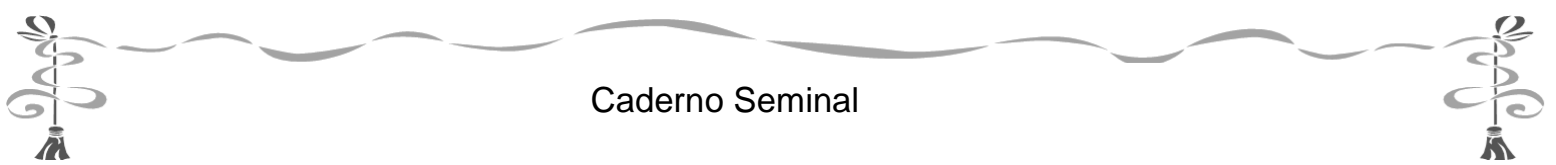

A citação apresentada recupera as marcas do cômico presentes também nas características das atividades lúdicas, entre elas a repetição, em Bergson; o prazer, em Platão, Aristóteles, Quintiliano e Cícero; a superação dos afetos dolorosos, na perspectiva freudiana.

Eni Puccinelli Orlandi (1996, p. 155), ao apresentar as características do discurso lúdico, reforça a proposta de aproximação entre o jogo e o cômico e, consequentemente, o humor, apontando o discurso lúdico como o uso da linguagem pelo prazer. Ressalta que, assim sendo, as funções da linguagem mais recorrentes seriam a poética e a fática por causa respectivamente da maneira como se dá a polissemia e por causa da reversibilidade nesse tipo de discurso A polissemia se instala na multiplicidade de sentidos, e a dominância de um sentido sob os outros, ecos desse sentido mesmo, realiza-se de maneira a ser preservado o máximo de ecos.

Considerando a natureza de nosso trabalho podemos sintetizar que o humor resulta da transformação (ou economia de despesa, no discurso freudiano) de dor em alegria, satisfação. $\mathrm{O}$ aspecto lúdico do humorismo resulta no uso da linguagem pelo prazer; é a ruptura com o instituído. No lúdico, assim como no humor, a relação com a referência não importa, não é necessária: há espaço para o nonsense. João Guimarães Rosa (1979, p. 3-12), no prefácio de "Tutameia", intitulado "Aletria e Hermenêutica" trata a questão do suprassenso na construção da comicidade e do humorismo. Diz ele:

\begin{abstract}
No terreno do Humour, imenso em confins vários, pressentem-se mui hábeis pontos e caminhos. E que na prática da arte, comicidade e humorismo atuem como catalisadores ou sensibilizantes ao alegórico espiritual e ao não prosaico, é verdade que se confere de modo grande. Risada e meia? Acerte-se nisso em Chaplin e em Cervantes. Não é o chiste rasa coisa ordinária; tanto seja porque escancha os planos da lógica, propondo-nos realidade superior e dimensões para mágicos novos sistemas de pensamento.
\end{abstract}

De circuito mais simplificado que o cômico, o humor pode iniciar e terminar em um único indivíduo, mas se comunicado ou compartilhado. Será através da compreensão da pessoa humorística que chegaremos ao mesmo prazer que ela irradia - o prazer humorístico.

Partindo-se da distinção proposta por Vladimir Propp entre o cômico e o humor, em que considera este a "capacidade de perceber e criar o cômico", podemos dividir a responsabilidade do riso entre aquele que cria o texto e o outro que o recria no momento da leitura desse produto. Divide-se a responsabilidade da construção do sentido humorístico entre o sujeito-produtor e o sujeito-leitor. A capacidade criativa e perceptiva do leitor também entra em ação e, consequentemente, o seu "estado de humor". Entretanto, o que faz rir a uns pode não despertar um mínimo de reação no outro.

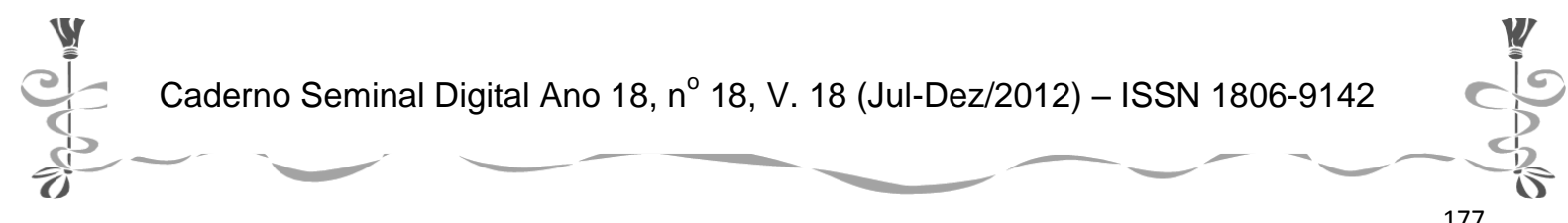




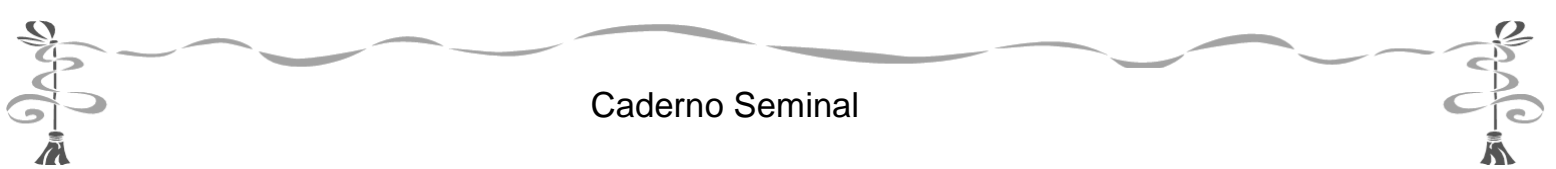

O risível - o objeto que nos faz rir - reside, então, onde? A leitura das crônicas de João Ubaldo Ribeiro nos aponta um humor mais subjetivo, aquele que tenta superar as inquietações interiores através do prazer que extrai da brincadeira com as palavras, construindo sentidos ora claros, ora jogando com a polissemia instaurada a partir da manipulação das palavras nos enunciados ou dos elementos constitutivos dessas palavras. Assim como Carlos Drummond de Andrade, o cronista não quer revirar a sociedade pelo avesso, ao colocar a nu as mazelas sociais ou bulir com o defeito do outro dolorosamente, mas tenta provocar modificações de ação, através da reflexão do outro sobre as indignações, os afetos que provocam o escritor.

O humor na crônica não carece ser claro, objetivo, ostensivo. Ao contrário, a ambiguidade é uma de suas marcas fortes. O tom irônico-humorístico que detectamos contribui com frequência na construção de efeitos de sentido pincelados ou derramados de humor. Perscrutamos neste artigo a veia humorística do autor como uma de suas marcas de estilo, aliada à expressividade que certas formações de palavras assumem nos textos. Lançando mão dessas estratégias no discurso, João Ubaldo Ribeiro trata as coisas sérias tentando não macular a leitura prazerosa de suas crônicas. É o deixar fruir por puro deleite de que nos falou Drummond.

Com frequência, o coloquialismo, outra marca estilística presente nos escritos de Ubaldo, permite o "bate-papo" com seus poucos e pacientes leitores. O cronista, que gosta de jogar conversa fora com seus interlocutores, confessa-se deprimido e alarmado com tanta desgraceira a que somos expostos ou que nos impõem. Matérias pesadelares, como diz o escritor. Assume que tem a obrigação de produzir textos mais leves: [...] eu devia procurar um assuntoz̨inho mais ameno, falar de amenidades inofensivas ("Paz, não é mesmo? $-20 / 06 / 1999)^{89}$.

Com relação à temática que seleciona, não difere daquelas que são alvo do cômico e permite ao cronista a exploração das técnicas discursivas na construção de efeitos de humor. A política em geral, os desacertos que dela advêm e os personagens que nela atuam, são alvos fáceis da pena do escritor:

Acordei com pendores filosófico-sociológicos, com perdão da má palavra. É uma bela e ensolarada manhã. Acordei com outona, em que uma brisazinha fresca balança as folhas dos pinhões roxos que agora resolveram dominar o terraço aqui de casa ("A gente se acostuma a tudo" - 18/04/1999)

O adjetivo composto filosófico-sociológicos faz referência às atividades intelectuais do Presidente da República. A princípio enobrecedor, adquire um caráter desprestigioso pelo tom irônico da expressão cristalizada empregada a seguir (com perdão da má palavra). A quebra de continuidade do tom cerimonioso promove o riso

\footnotetext{
${ }^{89}$ As expressões em itálico foram retiradas de algumas crônicas publicadas no jornal "O Globo", página de opinião que constituíram o córpus desta pesquisa.
}

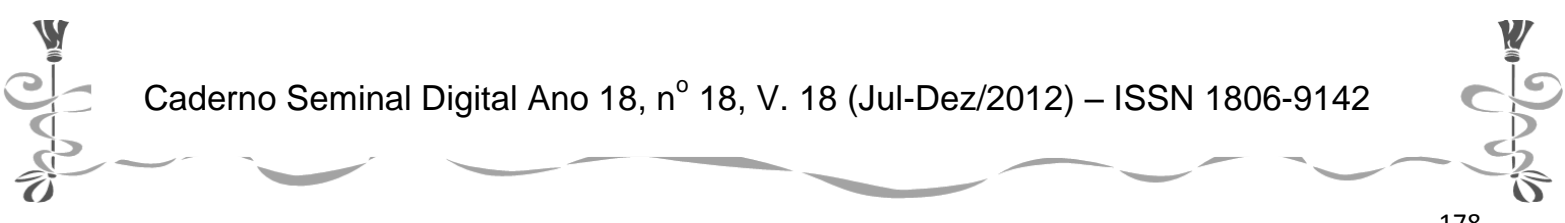




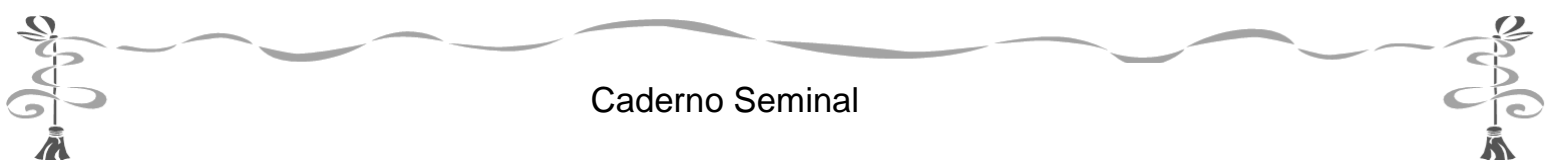

(ou o sorriso) de quem lê assim como também o jogo entre o nível culto da linguagem (acordei com pendores filosófico-sociológicos) e o nível coloquial da frase (com perdão da má palavra) a constrói a distensão do texto.

No geral, o tom das crônicas é casual e descontraído, permitindo, de quando em vez, ser invadido pelo trágico ou pelo lírico, o que não persiste por muito tempo. A crônica tende ao prosaico, ao despretensioso. No trecho comentado, é possível verificar-se que o objeto do riso se localiza no outro que, no caso, é a figura do Expresidente da República, Fernando Henrique Cardoso.

Mudando o foco, o autor transforma-se no objeto risível quando expõe as próprias precariedades, as suas limitações físicas e estéticas (calvície, obesidade, sexualidade, precariedade de saúde, vícios, a pouca habilidade em atividades esportivas). Desta forma dá voz às minorias, abrindo espaço para que outras vozes falem através de seu texto, instaurando a polifonia discursiva. É bem-humorada a definição que apresenta para minoria: "[...] qualquer categoria que tenha um denominador comum e se sinta por alguma coisa oprimida ou discriminada mesmo que seja maioria" (Política [Quem Manda, Por que Manda, Como Manda] ${ }^{90}$, 1995).

A definição irônico-humorística do que seja minoria vai ter como ponto alto a antonímia maioria. O desvio semântico de menor parte de para grupo oprimido também responde pelo sucesso da trama discursiva.

Recorrentes são os temas que versam sobre os problemas que atingem os vários segmentos da sociedade, notadamente aqueles causados pela inabilidade ou arbitrariedade do Poder Público. Explorando o viés cômico, seus textos falam da corrupção, do clientelismo, da falta de amor ao país, do descuido com a coisa pública, do desrespeito à cidadania brasileira, como ocorreu no episódio do "kitsocorro":

Ninguém está prestando atenção, mas é assim, à sorrelfa que as coisas pegam, como aconteceu com o kit de pronto-socorros... O otariado nacional comprou, a turma levou a grana, agora, tá na cara, que era só brincadeirinha. ("Problemas minoritários" - 07/03/1999) ${ }^{91}$

O emprego da formação neológica otariado para representar a ideia substantivocoletiva dos cidadãos que se preocuparam em cumprir a lei demonstra a posição ideológica do produtor do texto em relação ao fato apresentado, numa crítica direcionada aos autores da lei e àqueles que a cumpriram. Mais adiante, ainda no mesmo texto, o foco crítico recairá somente sobre o "rigor da Justiça brasileira". Agora, ironizando às claras projetos de lei estapafúrdios, cede a fala a um de seus

\footnotetext{
${ }^{90}$ RIBEIRO, João Ubaldo. Política (quem Manda, Por que Manda, Como Manda) (crônicas). Rio de Janeiro: Nova Fronteira, 1995.

${ }^{91}$ http://diariodonordeste.globo.com/1999/03/07/030004.htm
}

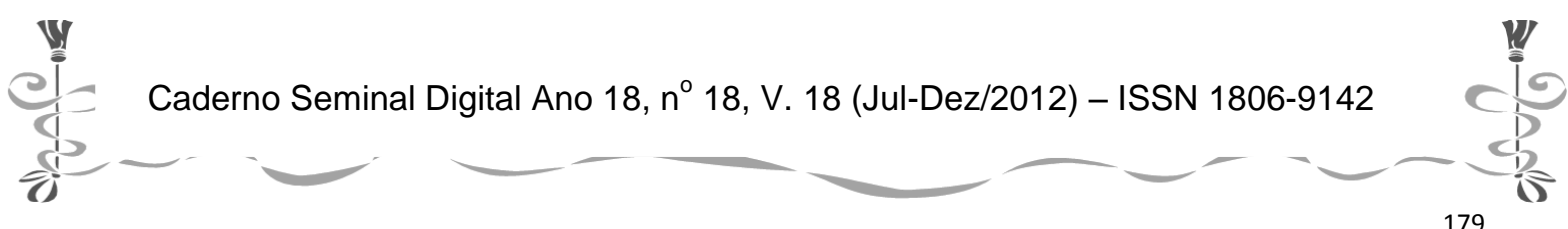




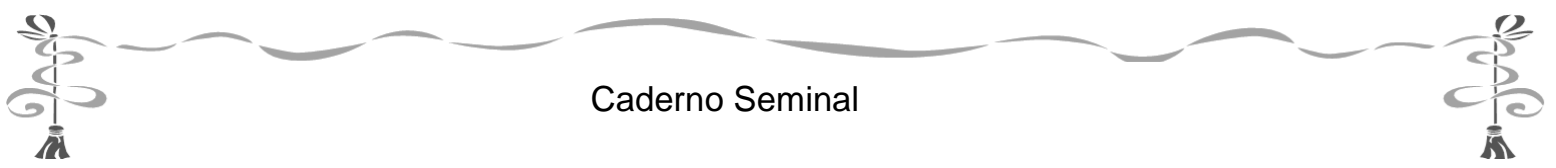

personagens co-botecanos, o Carlinhos Judeu, que propõe a institucionalização da piada:

O mesmo pode acontecer daqui a pouco. Você conta uma piada não está registrado no Conselho Federal de Contadores de Piada e paga multa ou cana inafiançável, ou as duas coisas, sabemos como o Brasil é com os crimes hediondos e poucos de nós são canadenses. ("Problemas minoritários" - 07/03/1999)

A expressão Conselho Federal de Contadores de Piada vai parodiar outros nomes de instituições federais julgadas "sérias" como o Conselho Federal de Educação, Conselho Federal de Medicina. Além disso, o emprego hiperbólico dos adjetivos inafiançáveis e hediondos contrasta com a pequenez do crime de contar uma piada. $\mathrm{O}$ lúdico se faz presente. O jogo de sentidos, o cruzamento de valores, construirá o verdadeiro sentido do texto, contando com a participação do interlocutor para arquitetar a mensagem em que a lei é "brincadeirinha" e a piada, "coisa séria", é o fato relevante aos olhos da Justiça brasileira.

Empregando a estratégia do humor para sinalizar o que destoa das convenções da sociedade e que precisa ser corrigido, característica funcional do cômico, o cronista não perde a oportunidade de chamar a atenção para a descaracterização da língua materna. De tempos em tempos, quando surge oportunidade, recupera o tema e, com finíssima ironia ou humor escancarado, traz à tona o problema dos modismos linguísticos, seu uso indiscriminado e muitas vezes desnecessário, principalmente no que diz respeito aos estrangeirismos adaptados ou não ao sistema da nossa língua. Vejamos uma passagem da crônica Meu Amarelo Manteigabicho (28/03/1999):

Eu ia escrever como se diz na língua-patroa, my yellow butterfly mas na qualidade de pioneiro (candango, aliás: pioneiro é o Homem) em nosso acelerado processo de integração na comunidade norte-americana, pensei, pensei, pensei e resolvi que seria exagero querer que todo o povo brasileiro passasse a falar bem inglês, assim de uma hora para outra [...]. Vamos primeiro nos acostumando à rica sintaxe da língua-patroa, que, ao contrário do nosso tartamudear neandertalesco, raramente admite adjetivos pospostos aos substantivos (o português admite e até costumeiramente os aconselha e ensaia para ver nuances de significado nesse troca-troca indecente de lugar na frase, perda de tempo cretina, o atraso é um horror).

Dissemos anteriormente, ao tratarmos do cômico de palavras, que, às vezes, o termo tomado no seu sentido literal, dicionarizado, ou mais popularmente, ao péda-letra, pode ser fonte de riso e propiciar momentos de saudável humor, a começar pelo título da crônica. $\mathrm{O}$ autor, ao fazer a tradução dos constituintes do termo inglês butterfly, percorre caminhos hilariantes até chegar a algumas formações compostas em português que, por serem fruto de um trabalho de tradução literal das bases que formam o vocábulo estrangeiro, resultam em significantes inusitados a que o leitor

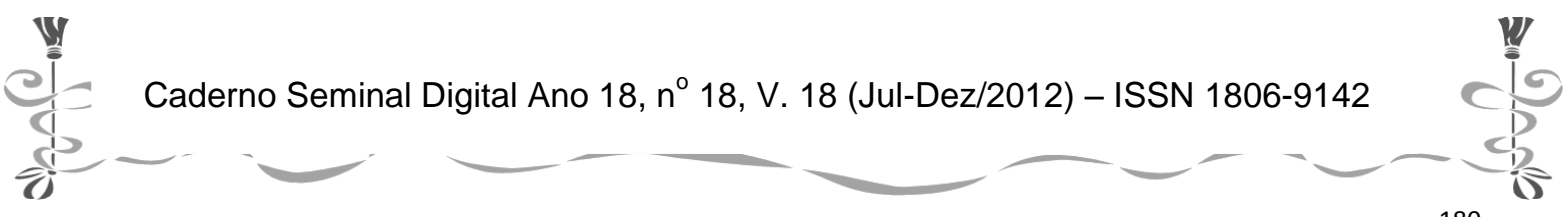




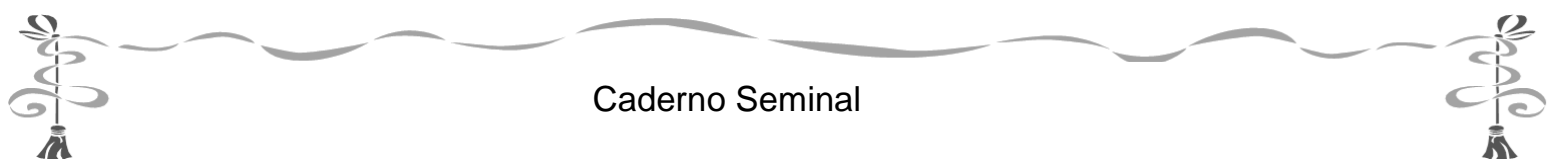

não costuma encontrar. A quebra de continuidade causa surpresa, leva ao riso. Butterfly, para nós, é borboleta, simplesmente. Percorrendo a significação literal das bases na língua, Ubaldo chega a construções como mosca-manteiga, bicho-manteiga, manteigabicho, butterbicho. Nota-se a presença do lúdico na composição dessas palavras, assim como na oposição língua-patroa / língua materna.

As formações neandertalesco, troca-troca, ao se referirem às práticas linguísticas do português, tal como caracterizam o sistema, fazem crítica severa ao processo de aculturação que sofremos por interferência norte-americana, em função da ideologia da globalização que nos é imposta a todo momento. Ainda nessa crônica, a reflexão sobre os problemas que atingem a língua materna avançam na direção de outras áreas do nosso universo linguístico:

Isto não quer dizer nada e vamos perseverar em nosso esforço de adquirir precisão verbal e escrever "penalizar" em vez desse verbo burro que é prejudicar e parar com essa mania de que preposições não são palavras para se acabar sentenças com. Para não falar em muitíssimas mazelas e muitíssimos defeitos de nosso expressar, com os quais lidar não tenho paciência de. ("Meu amarelo manteigabicho"- 28/03/1999) (grifos nossos)

É interessante observar que os trechos sublinhados se tornam humorísticos pela construção realizada por João Ubaldo, digamos "ao pé da letra", passando da abstração conceitual à concretização do fato, dando continuidade ao texto. A leitura literal do fragmento é suporte para a superposição de outra significação subjacente que o interlocutor deverá apreender e dessa forma tornar possível o descortinar da realidade linguística com que nos deparamos hoje. Cabe registrar que, embora seus textos apresentem várias marcas do nível coloquial da linguagem e registros próprios da oralidade, o escritor não descuida, no mais das vezes, da linguagem que emprega. O vocabulário é selecionado e não raro nos defrontamos com o eruditismo próprio de quem reverencia o idioma como instrumento de soberania e de resistência à dominação cultural; de quem ainda se orgulha e cuida com desvelo da última flor do Lácio e nela reconhece a beleza, o colorido e a riqueza de recursos expressivos. Essa atitude não é inconsciente, pois frequentemente nos intima a recorrer ao dicionário para buscar a significação de determinadas palavras que, pelo pouco uso, tornaramse desconhecidas para o leitor. Preocupa-se, enfim, com a estética dos seus textos, como veremos a seguir: "É, mas falei tanto que quase não sobrou espaço para minha borboleta. As borboletas não soem ser seres grandevos (uma aliteraçãozinha e um pernosticismozinho, só para tirar recalque), mas esta minha é."

Enveredando pelo campo da estilística como sendo o estudo dos fatos da expressão da linguagem do ponto de vista de seu conteúdo afetivo, isto é, a expressão da sensibilidade mediante a linguagem e a ação dos fatos da linguagem sobre a sensibilidade, nota-se que a forma como João Ubaldo Ribeiro lança mão dos

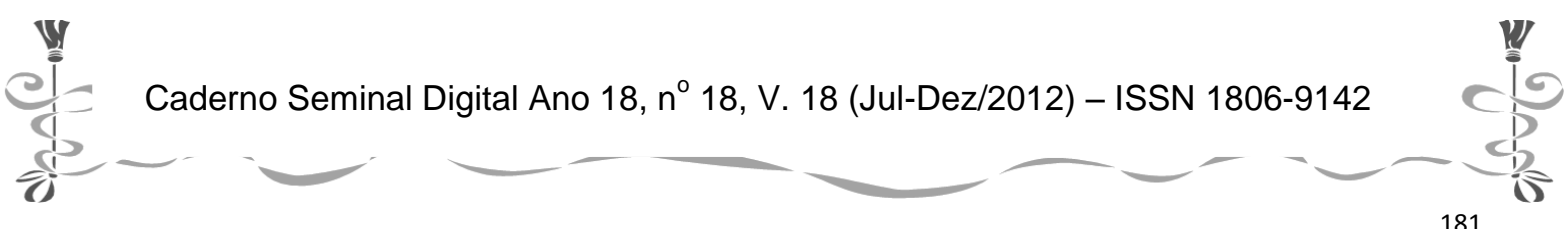




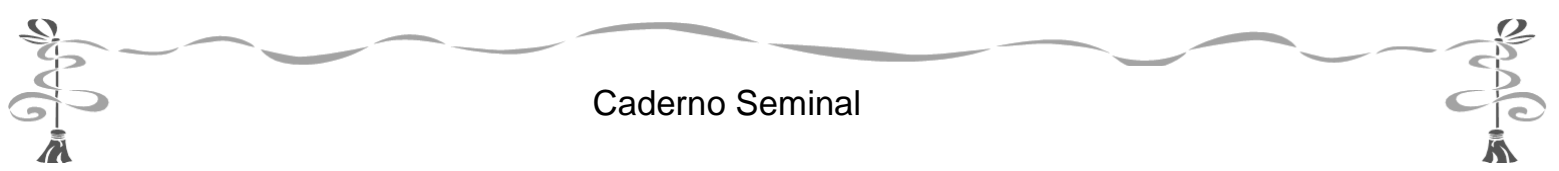

processos de formação de palavras é altamente eficiente na construção de efeitos de humor em seus textos, reconhecendo-os como recurso linguístico-expressivo.

Quando falamos em aproveitamento dos processos de formação de palavras, não reservamos exclusividade às formações neológicas. A exploração de formas já consagradas pelo uso linguístico, especialmente os adjetivos e os advérbios, dão ao texto um ornamento, um colorido grandemente expressivo. As palavras que aparecem, muitas vezes, atualizam o conceito das variações estilísticas, ou seja, a pluralidade de formas para exprimir um conceito similar: "Sim, pior seria se pior fosse, mas o fato é que está difícil pior ficar. Um médico americano, com muito sucesso, advoga um programa de saúde em que o sofrente deve comer alho e coisas que os livros sobre alimentação saudável nos dizem que devemos comer."

Não é muito comum encontrarmos o adjetivo sofrente em textos, uma vez que há a forma concorrente sofredor. Tanto o sufixo -nte quanto -(d) or são agentivos e pertencem ao sistema de sufixos da língua portuguesa. Entretanto, o cronista opta pela forma menos comum, o que ocasiona um acréscimo de expressividade, a ser percebida pelo leitor.

Outro recurso de geração de expressividade e humor é a construção neológica de várias palavras, algumas já apresentadas em exemplos citados anteriormente otariado, neandertalesco, pesadelares, língua-patroa. Com frequência, encontramos vocábulos constituídos a partir de processos de formação de palavras previstos pelo sistema da língua portuguesa. Predominantemente a derivação e a composição funcionam como gatilhos do riso nas crônicas de João Ubaldo, não só pelo efeito humorístico-expressivo que o cronista consegue extrair das formações inéditas, mas também pelo trabalho artesanal em combinar a semântica das bases aos morfemas prefixais e sufixais, nos casos de derivação, ou na reunião de bases, nas formações compostas. A necessidade momentânea de registrar uma ideia, nomear um fato, ou mesmo intensificá-lo expressivamente envolve o cronista nesse trabalho solitário de buscar insensatamente uma simples palavra ou expressão. $\mathrm{O}$ fragmento a seguir confirma essa ocorrência:

Antes que o prezado amigo ou encantadora senhora peguem da pena para escrever uma carta fulminando minha ignorância me apresso a reconhecer que a palavra "passarídeo" não existe, embora eu ache que devia existir. É como borboletáceo, criação famosa de um vestibulando de medicina em Salvador [“...] Pode haver quem prefira "lepidóptero", mas considero "borboletáceo" uma palavra necessária em nossa língua. Creio de bom alvitre procurar os préstimos do consagrado vate e meu amigo Geraldo Carneiro para ver se consigo que ele encaixe um borboletáceo num poema, assim legitimando seu ingresso no vernáculo.

Expressão de afetividade, os sufixos diminutivos são bastante recorrentes, ainda que assumam valores diferenciados, comprometidos que estão com o contexto onde aparecem registrados. Em algumas passagens, seu papel é meramente afetivo,

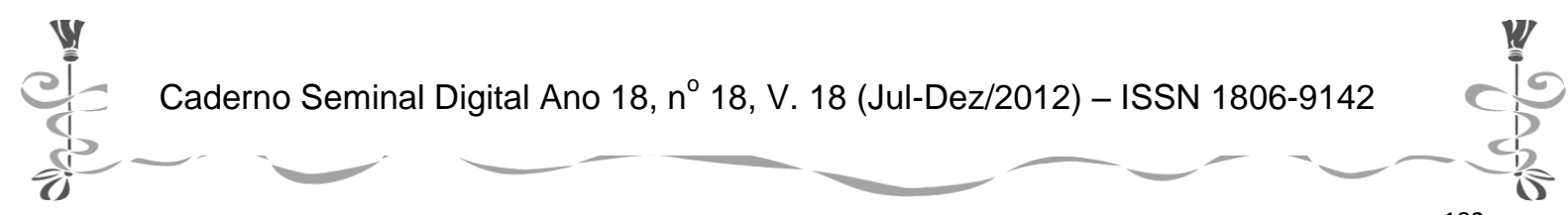




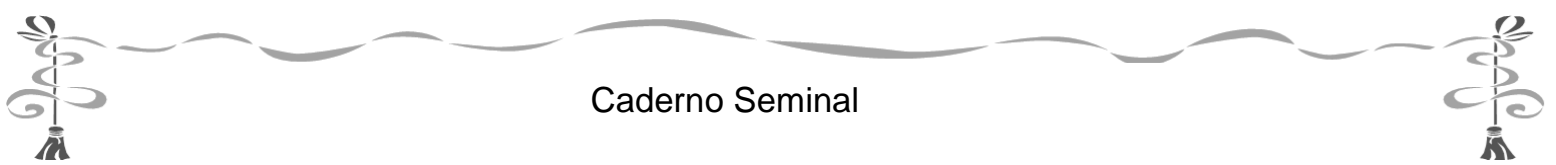

reflexo da subjetividade própria do estilo do autor e do gênero; em outras, sua função é a de instaurar efeitos de sentido irônico, não raro carregados de pejoratividade. Há ocorrências em que a formação diminutiva constrói sentidos hiperbólicos ou até mesmo superlativos.

Outros sufixos, como os superlativos, os aumentativos e o adverbial -mente também se prestam a essas variações semânticas, sempre pendentes da trama contextual para construírem sua significação.

\section{Considerações finais}

Como vimos observando até aqui, as crônicas escritas por João Ubaldo Ribeiro exemplificam com propriedade o gênero textual a que pertencem. Seu compromisso com o prazer do leitor faz com que, através dos recursos que a língua coloca a seu dispor, apresente a realidade, às vezes bastante dolorosa, travestida do agradável, da brincadeira, do lúdico.

À semelhança das teorias contemporâneas sobre o riso, é um outro viés para reflexão e apreensão do que acontece a nossa volta. A aparente irreverência alterna com a seriedade; a voz do outro é descontraída e relaxada e permuta com a voz do produtor do texto, às vezes, tensa e comprometida com a ideologia que subjaz. Apelando, porém à ironia, aos jogos de palavras, às hipérboles e outros recursos expressivos, desvia a atenção do interlocutor e consegue levá-lo à ambiência do humor.

Com relação aos recursos expressivos, são utilizados aqueles que frequentam outros textos do mesmo autor. Reservamos, porém, à palavra, às várias palavras que se revigoram expressivamente a cada texto, o mérito de fazer rir - ou sorrir - nos textos de Ubaldo. Cúmplices umas das outras, constroem os efeitos de sentido humorístico com que a crônica se caracteriza, sem abrir mão da responsabilidade que trazem em si de disparar os gatilhos do humor dentro do texto.

A habilidade com que o cronista - alquimista de palavras - manipula os elementos constitutivos dos vocábulos denota o conhecimento e o pleno domínio do sistema padrão da língua, sem esquivar-se, no entanto, de transferir para o informal toda a facilidade que tem para construir palavras novas ou garimpar cuidadosamente entre os morfemas do sistema aqueles que serão mais eficientes nas soluções expressivas de que o produtor do texto necessita.

Com esse trabalho artesanal, para o qual nosso olhar se volta com interesse específico nesta pesquisa, a crônica jornalística que, desavisadamente pode parecer um texto de fácil elaboração, adquire status literário. Segundo OLIVEIRA (1998: 27): É inegável que a obra de um escritor revelará seu dominio do subcódigo prestigiado pelos

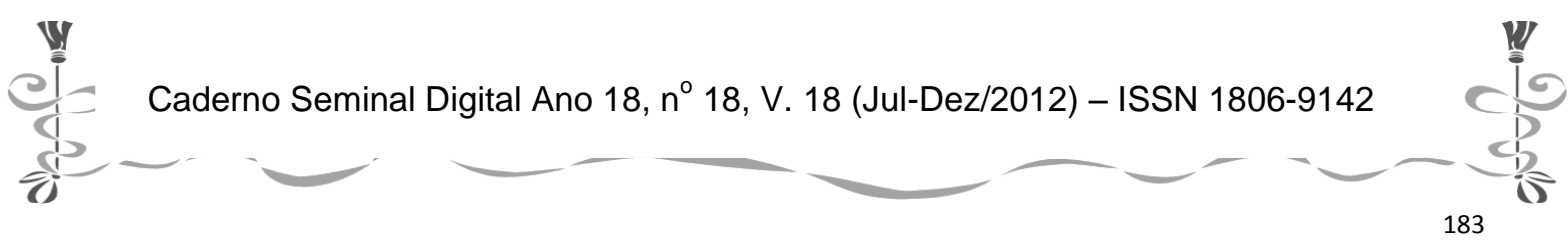




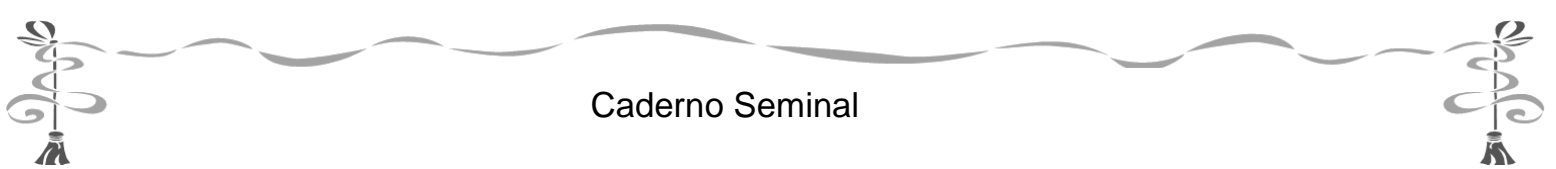

gramáticos. Quanto maior o conhecimento das regras do jogo linguístico, maior facilidade para se esquivar e trapacear; para criar, enfim. ${ }^{92}$

João Ubaldo Ribeiro com suas crônicas dinâmicas, atualizadoras e detentoras de humor de qualidade corrompe o sofrimento, relaxa a mente e quase sempre provoca um riso cúmplice nessa subversão do sério em busca do prazer, e de alguma forma, reforça o pensamento de que rir ainda é o melhor remédio.

\section{Referências}

ALBERTI, Verena. O riso e o risivel na história do pensamento. Rio de Janeiro: Jorge Zahar Ed, Fundação Getúlio Vargas, 1999.

BAIÃO, Rosaura de Barros. O discurso do humor. Rio de Janeiro: Dissertação de Mestrado em Linguística (digitada): UFRJ, 1993.

CABRAL, Álvaro \& NICK, Eva. Dicionário técnico de psicologia. São Paulo: Cultrix,1974. Livro Técnico, 1978.

ECO, Umberto. O nome da rosa. Rio de Janeiro: Record,1986.

FREUD, Sigmund. Os chistes e sua relação com o inconsciente. Trad. Jayme Salomão. Rio de Janeiro: Imago,1977.

MENEZES, Eduardo Diatay. "O riso, o cômico e o lúdico". In Revista de Cultura Vozes, Petrópolis,: n 1, 1974, p 5-14

OLIVEIRA, Maria Lília Simões de. A língua e o discurso da memória e a semântica da infância revisitada em Bartolomeu Campos Queirós. Dissertação de mestrado (digitada). Rio de Janeiro: UERJ, 1998.

ORLANDI, Eni Puccinelli. A linguagem e seu funcionamento. As formas do discurso. 4 ed. Campinas: Pontes,1966.

POSSENTI, Sírio. Os humores da língua. Análises linguísticas de piadas. Campinas: Mercado Letras, 1998.

PROPP, Vladimir. Comicidade e riso. Trad. Aurora Fornoni Bernardini e Homero Freitas de Andrade. São Paulo: Ática, 1992.

ROSA, Guimarães. Aletria e hermenêutica. In Tutameia; terceiras estórias. 5 ed. Rio de Janeiro: José Olympio,1979. p 3- 12.

SANDMANN, Antonio José. Formação de palavras no português brasileiro contemporâneo.

SALOMÉ, Consuelo. "Rir é o melhor capote". In Letras Hoje, n 79. PUC do Rio Grande Sul, 1990 p 61-78.

${ }^{92}$ OLIVEIRA, Maria Lilia Simões de. A língua e o discurso da memória: a semântica da infância revisitada em Bartolomeu Campos Queirós. Dissertação de mestrado (digitada). UERJ. 1998 p 27.

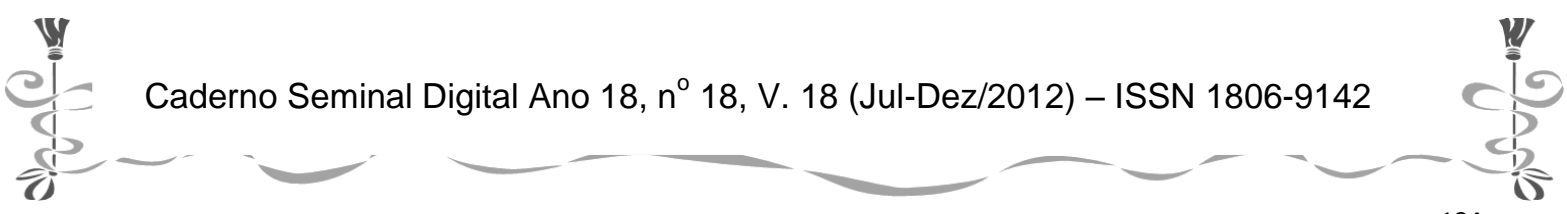




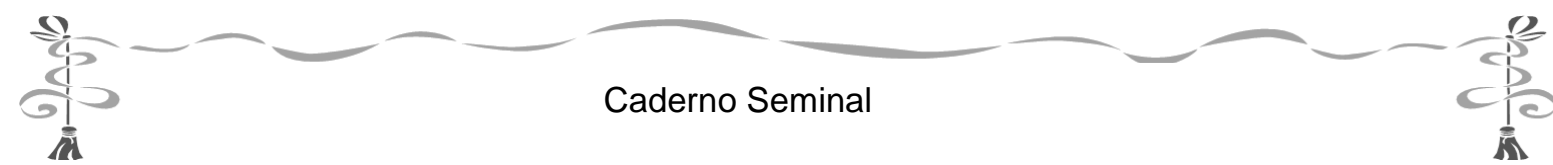

ZIRALDO et alii . "Ah! Humorismo a sério". Revista de Cultura Vozes. Petrópolis, vol. 3/ abril, 1970.

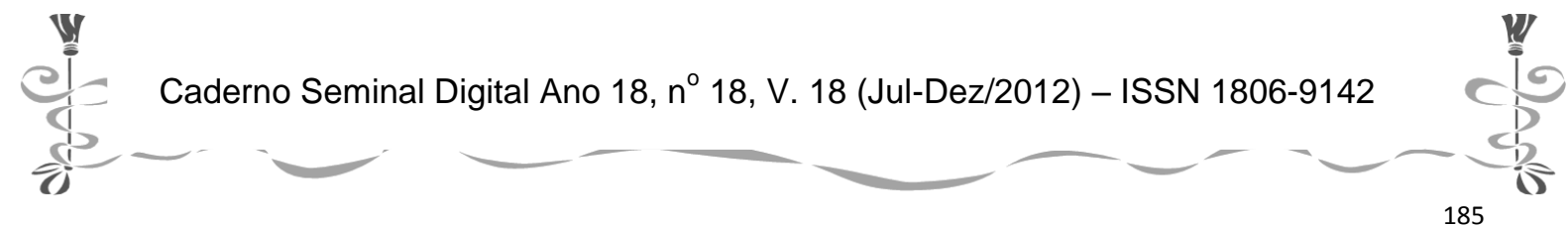

